\title{
Al Doping Effect on the Growth Rate Enhancement and Magnetic Properties of ZnO Nanorods Synthesized By Hydrothermal Method
}

\author{
Tang $\mathrm{XL}^{1}$, Young $\mathrm{SL}^{2 *}$, Chen $\mathrm{HZ}^{2}$, Kao $\mathrm{MC}^{2}$ and $\mathrm{Ou} \mathrm{CR}^{3 *}$ \\ ${ }^{1}$ Department of Electronic Engineering, Suzhou Institute of Industrial Technology, China \\ ${ }^{2}$ Department of Electronic Engineering, Hsiuping University of Technology, Taiwan \\ ${ }^{3}$ Department of Energy and Materials Engineering, Hsiuping University of Technology, Taiwan
}

Submission: July 13, 2017; Published: July 26, 2017

*Corresponding author: Young SL, Department of Electronic Engineering, Hsiuping University of Technology, Taiwan, Tel: +886-931-634256;

E-mail: slyoung@hust.edu.tw

Ou CR, Department of Energy and Materials Engineering, Hsiuping University of Technology, Taiwan; Email: crou@hust.edu.tw

\begin{abstract}
Well-defined Al-doped nanorods have been synthesized by a low temperature hydrothermal method. The XRD patterns of all compositions with single diffraction peak (002) show the same wurtzite hexagonal structure. The length and diameter of the Al-ZnO nanorods observed by FESEM increase with the increase of Al doping indicating the enhancement of growth rate by the doping of Al. Photoluminescence spectra showed a red-shift of the UV emission peak position indicating the substitution of $\mathrm{Al}$ for $\mathrm{Zn}$. Ferromagnetism is observed from the results of magnetization measurement. The increase of the saturation magnetization reveals an association with the increase of defects induced by the doping of the Al in the nanorods
\end{abstract}

Keywords: ZnO; Hydrothermal method; Ferromagnetism; Oxygen vacancies

Abbreviations: DMS: Diluted Magnetic Semiconductor; MS: Saturation Magnetization; MHC: M-H curves: Magnetization Curves; BMPs: Bound Magnetic Polarons

\section{Introduction}

Recently, ZnO-based diluted magnetic semiconductor (DMS) has attracted much attention for their possible use as biomedical materials. Low dimensional nano structured ZnO DMS, such as polycrystalline films, nanorods and nono particles could provide a biocompatible/biodegradable platform for development of high performance biosensing and biomedical applications due to their unique fundamental material properties [1]. Zinc oxide can exhibit a wide variety of nanostructures synthesized by various methods resulting in uniquely semiconducting, optical and piezoelectric properties for applications [2]. Chemically, nano structured $\mathrm{ZnO}$ exhibits a significant increase of -OH groups on the surface, which can be readily functioned by various surface decorating molecules. Furthermore, natures of low toxicity and biodegradability enforce $\mathrm{ZnO}$ to be the potential candidate for biomedical applications, such as biomedical imaging, biomagnetic therapy, drug delivery, gene delivery, and biosensing of a wide array of molecules of interest [3].

\section{Discussion}

The $\mathrm{Zn}_{1-x} \mathrm{Al}_{\mathrm{x}} \mathrm{O}$ nanorods ( $\mathrm{x}=0.01,0.02$ and 0.04 ) were fabricated on the $\mathrm{ZnO}$ seeded silicon substrate by the hydrothermal method. The source solutions for Zn1-xAlxO nanorods growth were prepared using the precursors, zinc acetate dihydrate $\left[\mathrm{Zn}\left(\mathrm{C}_{2} \mathrm{H}_{3} \mathrm{O}_{2}\right) 2 \cdot 2 \mathrm{H}_{2} \mathrm{O}\right]$, aluminium nitrate nonohydrate $\left[\mathrm{Al}\left(\mathrm{NO}_{3}\right)_{3} \bullet 9 \mathrm{H}_{2} \mathrm{O}\right]$ and hexamethylenetetramine $\left[\left(\mathrm{CH}_{2}\right]_{6} \mathrm{~N}_{4}\right]$ dissolved in the DI water. The metal ions in stoichiometric mole ratios and hexamethylenetetramine were both kept at $0.02 \mathrm{M}$. Then, the seeded substrate was placed upside down into the solutions separately in a closed vial at 90 ${ }^{\circ} \mathrm{C}$ for $3 \mathrm{~h}$ to grow the nanorods. Finally, the samples were rinsed with de-ionized water and dried in air for characterization.

Al-doped $\mathrm{ZnO}$ nanorods have been fabricated on Si substrates separately by a low temperature hydrothermal method. The as synthesized nanorods with a uniform array nanostructure have 


\section{Global Journal of Nanomedicine}

been observed by FE-SEM as shown in Figure 1. The radius and length of Al-doped $\mathrm{ZnO}$ nanorods is larger than that of pure $\mathrm{ZnO}$ which indicates the growth rate of the Al-doped nanorods can be obviously enhanced by the introduction of Al. The XRD patterns of all compositions with single diffraction peak (002) are shown in Figure 2 which reveals the same wurtzite hexagonal structure. Besides, the (002) diffraction peak of the $\mathrm{Zn}_{1-\mathrm{x}} \mathrm{Al}_{\mathrm{x}} \mathrm{O}$ nanorod arrays shift slightly to larger $2 \theta$ values from $34.54^{\circ}$ of $\mathrm{x}=0.01,34.58^{\circ}$ of $\mathrm{x}=0.02$, to $34.66^{\circ}$ of $\mathrm{x}=0.04$, which indicates the effective substitution of $\mathrm{Zn}$ by $\mathrm{Mg}$ and the consequent decrease of lattice constants due to the smaller ionic radius of $\mathrm{Al}^{3+}$ ion

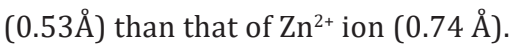

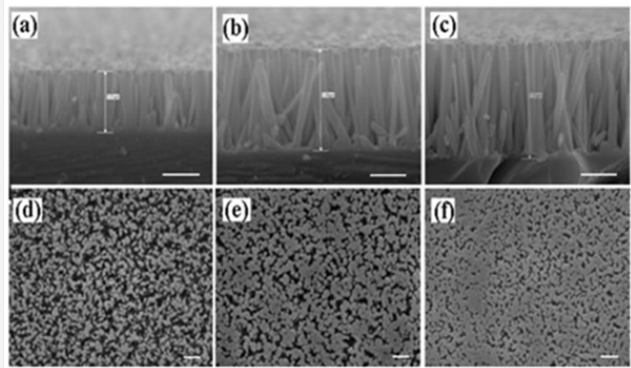

Figure 1: Cross-section images of $\mathrm{Zn1-xAlxO}$ nanorods with (a) $x=0.01$, (b) $x=0.02$, and (c) $x=0.04$. Top view images of Zn1$x A l x O$ nanorods with (a) $x=0.01$, (b) $x=0.02$, and (c) $x=0.04$. All scale bars denote $1 \mu \mathrm{m}$.

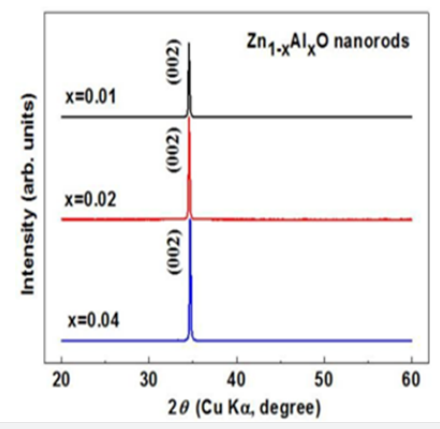

Figure 2: X-ray diffraction patterns of the $\mathrm{Zn} 1-\mathrm{xAlxO}$ nanorods with $x=0.01,0.02$ and 0.04 .

Photoluminescence spectra are measured for crystallization and defect observation. As shown in Figure 3, the red-shifted UV emission of the $\mathrm{Zn}_{1-\mathrm{x}} \mathrm{Al}_{\mathrm{x}} \mathrm{O}$ nanorods from $\mathrm{x}=0.01$ to 0.04 indicates the substitution of $\mathrm{Al}$ for $\mathrm{Zn}$. Besides, the ratio of visible to UV emission intensities (denoted as IVIS/IUV) of the Zn1-xAlxO shows a slight increase, which also indicates an increase of the defects and a suppression of crystallinity of the Zn1-xAlxO nanorod arrays. The magnetic field dependence magnetization curves (M-H curves) of the Al-doped $\mathrm{ZnO}$ nanorods are shown in Figure 2. All samples show ferromagnetic ordering at room temperature. Saturation magnetization (MS) increases from $0.317 \mathrm{emu} / \mathrm{g}$ for $\mathrm{x}=0.01$, to $0.581 \mathrm{emu} / \mathrm{g}$ for $\mathrm{x}=0.02$ to $0.993 \mathrm{emu} / \mathrm{g}$ for $\mathrm{x}=0.02$ of the $\mathrm{Zn}_{1-\mathrm{x}} \mathrm{Al}_{\mathrm{x}} \mathrm{O}$ nanorods. The ferromagnetism is enhanced and saturated magnetization is increased with the doping of $\mathrm{Al}$ into the $\mathrm{ZnO}$ nanorods. The ferromagnetism for the $\mathrm{Zn}_{1-\mathrm{x}} \mathrm{Al}_{\mathrm{x}} \mathrm{O}$ nanorods originates from the increase of the defect trapped electrons magnetized by external magnetic field, which can be clarified with the bound magnetic polarons (BMPs) model proposed by Coey et al. [4]. During the process of the hydrothermal reaction, defects can be easily introduced and be increased fatherly by $\mathrm{Al}$ doping due to lattice mismatch (Figure $4)$.

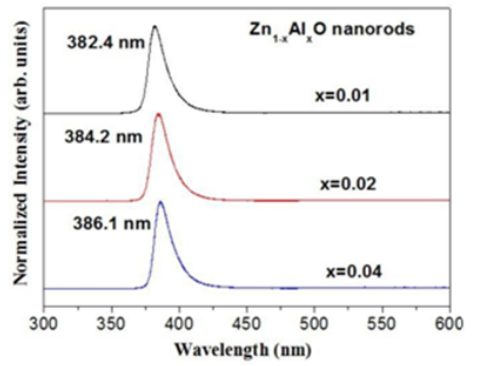

Figure 3: Photoluminescence spectra of the $\mathrm{Zn} 1-\mathrm{xAlxO}$ nanorods with $\mathrm{x}=0.01,0.02$ and 0.04 .

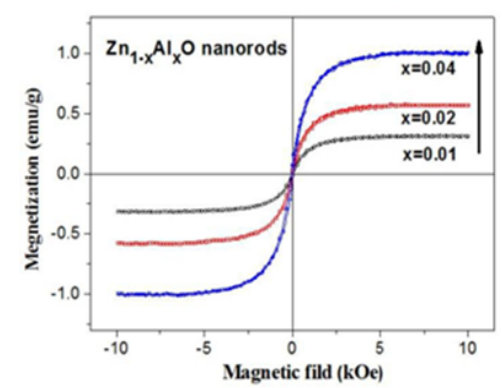

Figure 4: Magnetization curves of the $\mathrm{Zn1} 1-\mathrm{xAlxO}$ nanorods with $\mathrm{x}=0.01,0.02$ and 0.04 .

\section{Conclusion}

The Al-doped nanorods have been hydrothermally fabricated for the comparison of microstructure and magnetism. The single phase of the wurtzite hexagonal structure is obtained for all compositions. The increase of length and diameter of $\mathrm{ZnO}$ nanorods indicates that the growth rate is significantly influenced by the doping of Al. The field dependence magnetization measurements show room temperature ferromagnetism for all nanorods. The saturation magnetization shows the obvious increase of the $\mathrm{Al}$-doped nanorods with $\mathrm{Al}$ concentration.

\section{References}

1. Owens GJ, Singh RK, Foroutan F, Alqaysi M, Han CM, et al. (2016) Solgel based materials for biomedical applications. Progress in Materials Science 77: 1-79.

2. Ahmad M, Zhu J (2011) ZnO based advanced functional nanostructures: synthesis, properties and applications. Journal of Materials Chemistry 21(3): 599-614. 
3. Zhang Y, Nayak TR, Hong H, Cai W (2013) Biomedical applications of zinc oxide nanomaterials. Curr Mol Med 13(10): 1633-1645.

This work is licensed under Creative Commons Attribution 4.0 License

BY

DOI: $10.19080 / G . J N .2017 .02 .555592$
4. Coey JMD, Venkatesan M, Fitzgerald CB (2005) Donor impurity band exchange in dilute ferromagnetic oxides. Nat Mater 4(2): 173-179.

Your next submission with JuniperPublishers will reach you the below assets

- Quality Editorial service

- Swift Peer Review

- Reprints availability

- E-prints Service

- Manuscript Podcast for convenient understanding

- Global attainment for your research

- Manuscript accessibility in different formats

( Pdf, E-pub, Full Text, Audio)

- Unceasing customer service

Track the below URL for one-step submission https://juniperpublishers.com/submit-manuscript.php 